\title{
Synthetic avenues towards a tetrasaccharide related to Streptococcus pneumonia of serotype 6A
}

\author{
Aritra Chaudhury ${ }^{1,2}$, Mana Mohan Mukherjee ${ }^{1,3}$ and Rina Ghosh ${ }^{* 1}$
}

\author{
Full Research Paper \\ Address: \\ ${ }^{1}$ Department of Chemistry, Jadavpur University, 188, Raja S. C. \\ Mullick Rd., Kolkata 700032, India, ${ }^{2}$ Department of Chemical \\ Sciences, Indian Institute of Science Education and Research, \\ Kolkata, Mohanpur, 741246, West Bengal, India and ${ }^{3}$ present \\ addrress: Laboratory of Bioorganic Chemistry, NIH, NIDDK, \\ Bethesda, MD, USA \\ Email: \\ Rina Ghosh* - ghoshrina@yahoo.com \\ * Corresponding author

\section{Keywords:} \\ carbohydrates; glycosylation; oligosaccharides; stereoselectivity; total \\ synthesis \\ Beilstein J. Org. Chem. 2018, 14, 1095-1102. \\ doi:10.3762/bjoc. 14.95 \\ Received: 26 February 2018 \\ Accepted: 26 April 2018 \\ Published: 17 May 2018 \\ Associate Editor: S. Flitsch \\ (c) 2018 Chaudhury et al.; licensee Beilstein-Institut. \\ License and terms: see end of document.
}

\begin{abstract}
Streptococcus pneumonia (SPn) is a Gram-positive bacterium which causes life threatening diseases. The bacteria protect themselves against non-specific host defence by an external polysaccharide (PS) capsule which bears a repeating unit, $\alpha$-D-Galp(1->3)$\alpha$-D-Glcp(1->3)- $\alpha$-L-Rhap(1->3)-D-Rib (SPn 6A). A closer look at the structure reveals the presence of $\alpha$-linked galactose and glucose residues. The synthesis of these 1,2-cis glycosidic linkages are considered challenging particularly in the context of a onepot oligosaccharide synthesis. We have synthesized the aforesaid tetrasaccharide (SPn 6A) based on both stepwise and sequential one-pot glycosylation reactions using easily accessible common building blocks; eventually similar overall yields were obtained in both cases.
\end{abstract}

\section{Introduction}

Complex glycans serve as attractive targets for carbohydratebased vaccines and therapeutics [1-3]. Streptococcus pneumonia (SPn) has been posing a serious threat in recent times. It is a major cause of pneumonia, bacteraemia, and meningitis in immune-compromised patients, elderly and children. A UNICEF/WHO survey has estimated that 920136 children died of pneumonia in 2015 accounting for $16 \%$ of all fatalities under the age of five [4]. Out of over 90 serotypes that have been reported for SPn [5,6], serogroup 6 has been ranked among the

most important causes of invasive pneumonococcal diseases [7]. These facts have led to extensive research towards the establishment of polysaccharide structures associated with the SPn serogroup 6 [8,9] (Figure 1).

Initially, it was thought that due to their similar carbohydrate core structures the antibodies elicited by SPn 6A would be effective against SPn 6B as well [10-13]. But recent studies have shown that serotype specific immune responses are 


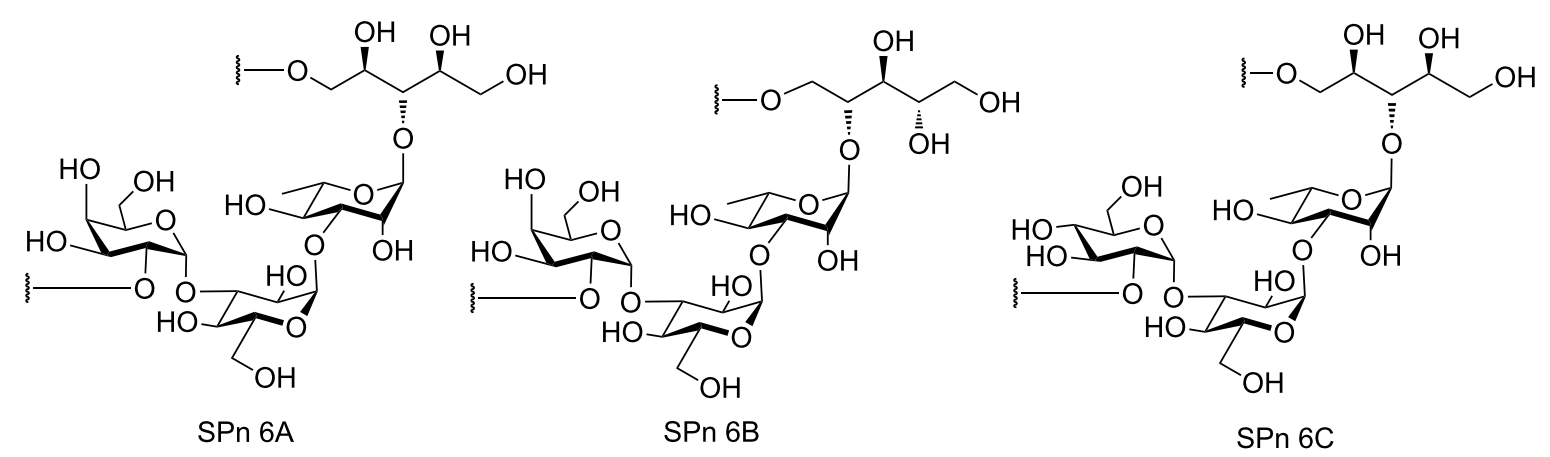

Figure 1: The tetrasaccharides associated with the pneumonicoccal serogroup 6 .

elicited by the antibodies and that they cross react slowly [14]. As a result the importance of the presence of the capsular polysaccharide of SPn 6A in multicomponent vaccines like Pneumovax ${ }^{\circledR}$ has been recognized [15]. The low hydrolytic stability of the phosphodiester linkages in the clinical isolates of the SPn $6 \mathrm{~A}$ polysaccharides poses a major drawback as it leads to low bioavailability [16]. Hence, the requirements of pure SPn 6A conjugate in proper amounts for future vaccine development can only be met via chemical synthesis. Therefore, a number of syntheses targeting the SPn 6A tetrasaccharide has been reported in literature. Initial reports of a linear synthesis were made by Vliegenthart et al. in the nineties [17-21]. After this, the Demchenko group improved these early reports with a convergent approach using glycosyl thioimidates as complementary glycosyl donors with respect to thioglycosides [22-25].
Herein, we wish to report synthetic routes to the SPn 6A tetrasaccharide via stepwise as well as one-pot sequential glycosylation strategies.

\section{Results and Discussion}

Keeping in mind our objective to synthesize the SPn 6A tetrasaccharide following stepwise as well as one-pot synthetic strategies based on common building blocks, a retrosynthetic analysis was made which led us to galactose-based donor 2 [26], ribitol-based acceptor 7 [22] and a gluco-rhamno-based disaccharide $(\mathbf{3 a} / \mathbf{3 b})$ to contemplate the synthesis of the tetrasaccharide derivative 1 (Figure 2).

The disaccharides $(\mathbf{3 a} / \mathbf{3 b})$ can be synthesized from their parent monomeric units $\mathbf{6 a / 6 b / 6 c}$ and 5 [27]. To ensure high $\alpha$-selec-

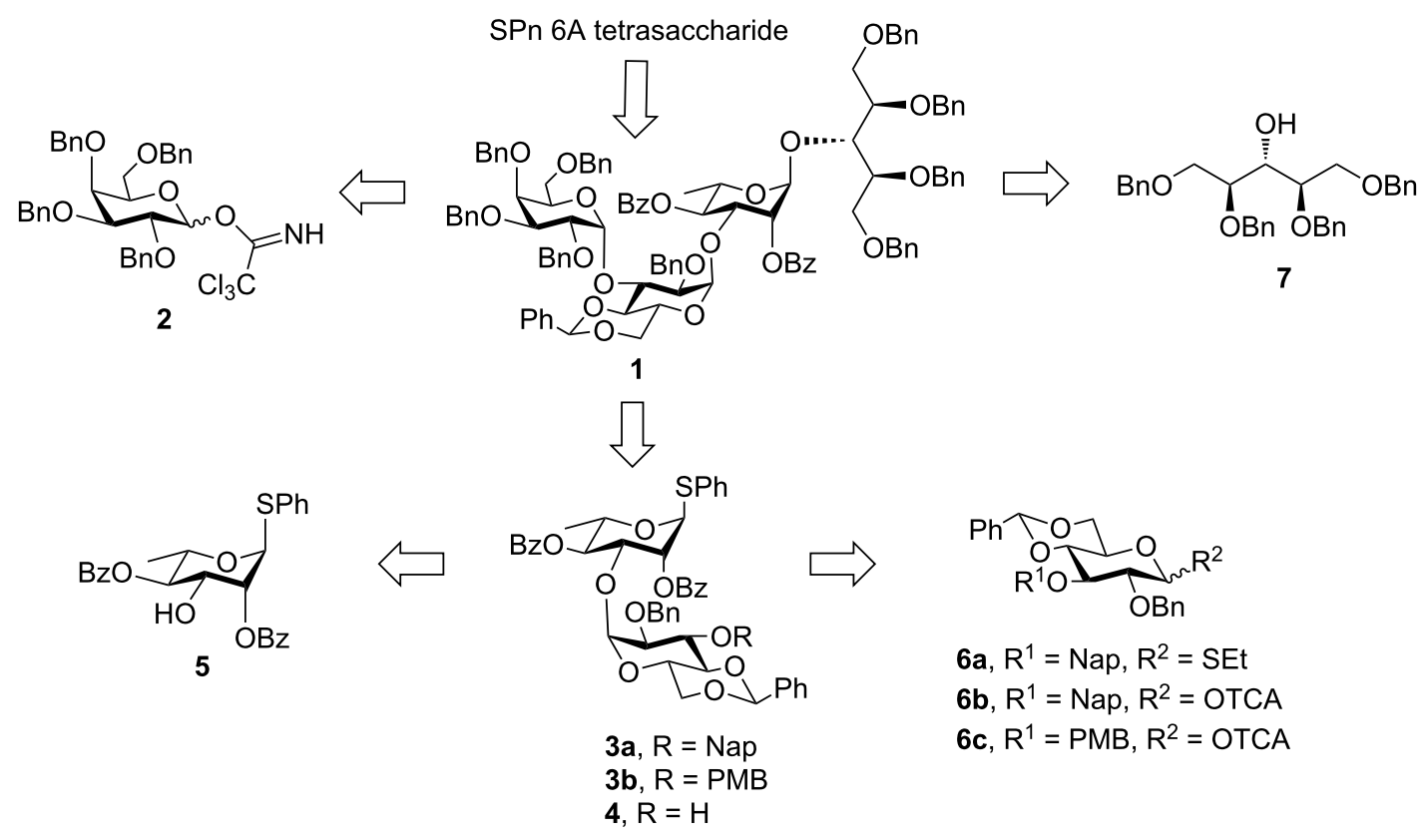

Figure 2: Retrosynthetic analysis. 
tion during the formation of the central gluco-rhamno disaccharide the benzylidene protected glucosyl donor (Figure 2) was selected, because the induction of the 1,2-cis selectivity in benzylidene-protected substrates via torsional/electronic effects have already been recognized [28].

The galactosyl trichloroacetimidate donor 2 was prepared following literature procedures [26]. On the other hand the D-glucosyl thioglycoside 8 was converted to the known benzylidene derivative $9[29,30]$ according to our previously reported procedure. Benzylation of 9 under phase-transfer conditions led to $\mathbf{1 0}$ [31] in $49 \%$ yield (Scheme 1). Subsequently, 10 was subjected to naphthylmethylation/ $p$-methoxybenzylation [32] with 2-(bromomethyl)naphthalene (NapBr)/p-methoxybenzyl chloride in DMF to afford $\mathbf{6 a} / \mathbf{1 1}$ [32] in $90 \%$ and $80 \%$ yields, respectively.

These derivatives were next subjected to thioglycoside hydrolysis using trichloroisocyanuric acid (TCCA) [33] in wet acetone which provided $\mathbf{1 2 a} / \mathbf{1 2 b}$ [34] in $85 \%$ and $89 \%$ yields, respectively. These were finally converted to their corresponding trichloroacetimidate $\mathbf{6 b} / \mathbf{6 c}$ [34] (Scheme 1) with yields of $93 \%$ and $90 \%$, respectively.

The L-rhamnosyl thioglycoside $\mathbf{1 4}[29,30]$, prepared from L-rhamnose (13), was deacetylated quantitatively in the presence of $\mathrm{Et}_{3} \mathrm{~N} / \mathrm{MeOH} / \mathrm{H}_{2} \mathrm{O}$ [35], and then stannylene-mediated selective naphthylmethylation at the $\mathrm{O}-3$ position was carried out to give the known derivative $\mathbf{1 5}$ in $82 \%$ yield [36]. This was next benzoylated almost quantitatively to give 16. Finally DDQ-mediated deprotection of the naphthylmethyl group gave the acceptor 5 [27] in 83\% yield (Scheme 2).

For acceptor 7 (Figure 2) ribitol 17 was converted to its corresponding diisopropylidene derivative $\mathbf{1 8}$ [37] in the presence of

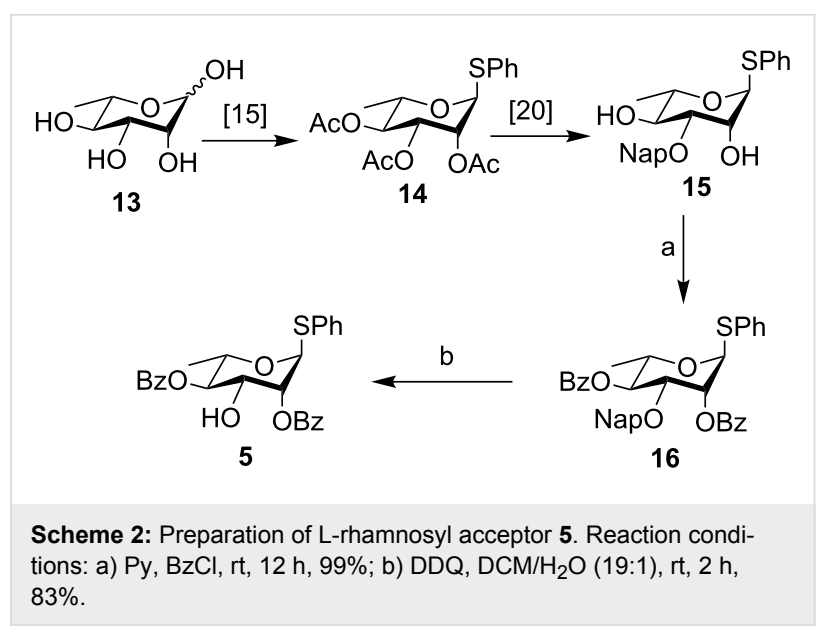

dimethoxypropane and $p$ TSA in acetone. Treatment with $\mathrm{NapBr}$ and $\mathrm{NaH}$ in DMF gave compound 19 in $93 \%$ yield. Subsequent deprotection of isopropylidene ketal with $p \mathrm{TSA} / \mathrm{MeOH}$ (aq) and then benzylation furnished $\mathbf{2 0}$ in $95 \%$ yield over two steps. Deprotection of the naphthylmethyl group in the presence of DDQ in aqueous dichloromethane (19:1) gave the glycosyl acceptor 7 [22] in $85 \%$ yield (Scheme 3).

In order to construct the central disaccharide fragment $\mathbf{3}$ in high yield with 1,2-cis selectivity, several glycosylation reactions using glucosyl donors $\mathbf{6 a} / \mathbf{6 b} / \mathbf{6 c} / \mathbf{1 2 a}$ and rhamnosyl acceptor 5 were contemplated. None of the conditions, based on the use of thioglycoside 6a as the glycosyl donor and separately, BSP/ $\mathrm{Tf}_{2} \mathrm{O}$ (Table 1, entry 1) or $\mathrm{Ph}_{2} \mathrm{SO} / \mathrm{Tf}_{2} \mathrm{O}$ (Table 1, entry 2 ) as the corresponding activators, or based on 1-hydroxy donor 12a and $\mathrm{Ph}_{2} \mathrm{SO} / \mathrm{Tf}_{2} \mathrm{O}$ (Table 1 , entry 3 ), could furnish any desired result. After trying with the mentioned donors, and reagent combinations (Table 1), we switched over to utilize trichloroacetimidate donors (6b, Table 1, entries 5 and 6, and $\mathbf{6 c}$, entry 4); the TMSOTf mediated glycosylation in $\mathrm{DCM} / \mathrm{Et}_{2} \mathrm{O}$ solvent<smiles>CC[SiH2]C(O)C(O)C(O)C(CO)CO</smiles><smiles>CCCC</smiles>

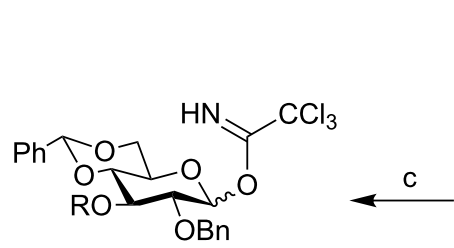

6b, $\mathrm{R}=\mathrm{Nap}$

6c, $R=P M B$<smiles>CC[SiH2]C1OC2COC(OC2c2ccccc2)C(O)C1O</smiles><smiles>C1CCCC1</smiles><smiles>CC[Si]C1(Br)OC2COC(OC2c2ccccc2)C(O)C1O</smiles>
a

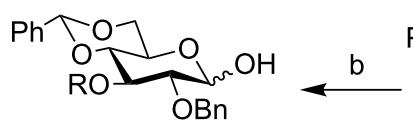

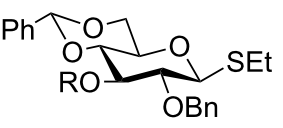

$R=\operatorname{Nap} 12 a$ 6a, $R=$ Nap

11, $R=P M B$ 

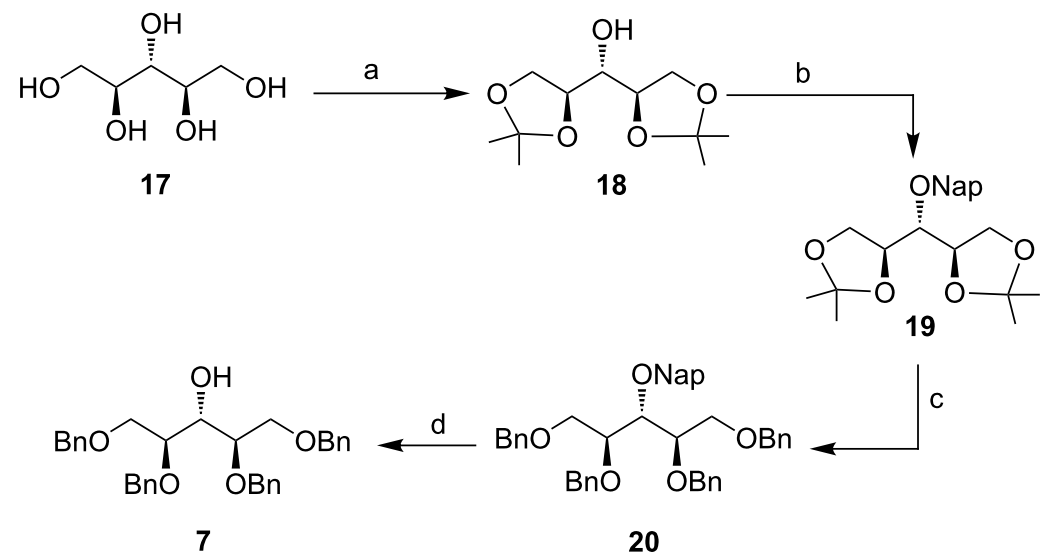

Scheme 3: Preparation of ribitol acceptor 7. Reaction conditions: a) $\mathrm{Me}_{2} \mathrm{C}(\mathrm{OMe})_{2}, \mathrm{pTSA}, \mathrm{CH}_{3} \mathrm{COCH}_{3}, \mathrm{rt}, 81 \%$; b) $\mathrm{NapBr}, \mathrm{NaH}, \mathrm{DMF}, \mathrm{rt}, 8 \mathrm{~h}, 93 \%$; c) (i) $p \mathrm{TSA}, \mathrm{MeOH}, 40^{\circ} \mathrm{C}, 4 \mathrm{~h}$, (ii) $\mathrm{BnBr}, \mathrm{NaH}, \mathrm{DMF}, \mathrm{rt}, 12 \mathrm{~h}, 95 \%$ over 2 steps; d) DDQ, DCM/ $\mathrm{H}_{2} \mathrm{O}$ (19:1), rt, $2 \mathrm{~h}, 85 \%$.

\begin{tabular}{|c|c|c|c|c|}
\hline Entry & Donor & Acceptor & Conditions & Yielda \\
\hline 1 & & $\underset{5}{\mathrm{OH}}$ & $\begin{array}{l}\mathrm{BSP}^{\mathrm{b}}, \mathrm{Tf}_{2} \mathrm{O}, \mathrm{DCM}, \\
-60^{\circ} \mathrm{C} \rightarrow \mathrm{rt}(\mathrm{A})^{\mathrm{c}}\end{array}$ & N.R. ${ }^{d}$ \\
\hline 2 & & $\begin{array}{r}\mathrm{OH} \\
5\end{array}$ & $\begin{array}{l}\mathrm{Ph}_{2} \mathrm{SO}, \mathrm{TTBP}, \mathrm{Tf}_{2} \mathrm{O}, \mathrm{DCM}, \\
-60^{\circ} \mathrm{C} \rightarrow-40^{\circ} \mathrm{C}(\mathrm{B})^{\mathrm{C}}\end{array}$ & N.R. ${ }^{e}$ \\
\hline 3 & & 5 & $\begin{array}{l}\mathrm{Ph}_{2} \mathrm{SO}, \mathrm{TTBP}, \mathrm{Tf}_{2} \mathrm{O}, \mathrm{DCM}, \\
-60^{\circ} \mathrm{C} \rightarrow-40^{\circ} \mathrm{C}(\mathrm{B})^{\mathrm{C}}\end{array}$ & N.R. ${ }^{d}$ \\
\hline 4 & & $\begin{array}{r}\mathrm{OH} \\
5\end{array}$ & $\begin{array}{l}\text { TMSOTf, DCM, } \\
-30^{\circ} \mathrm{C}(\mathrm{C})^{\mathrm{C}}\end{array}$ & N.R. ${ }^{f}$ \\
\hline 5 & ${ }_{6 b}^{\mathrm{OBr}}$ & $\begin{array}{r}\mathrm{OH} \\
5\end{array}$ & $\begin{array}{l}\text { TMSOTf, DCM, } \\
-10^{\circ} \mathrm{C}(\mathrm{C})^{\mathrm{C}}\end{array}$ & $\begin{array}{l}3 a, \\
54 \% \\
\text { ( } \alpha \text { only) }\end{array}$ \\
\hline 6 & $6 \mathrm{~b}$ & $\begin{array}{r}\mathrm{OH} \\
5\end{array}$ & $\begin{array}{l}\text { TMSOTf, DCM/Et }{ }_{2} \mathrm{O}(5: 1) \\
-30^{\circ} \mathrm{C}(\mathrm{C})^{\mathrm{C}}\end{array}$ & $\begin{array}{l}3 a, \\
75 \% \\
\text { ( } \alpha \text { only) }\end{array}$ \\
\hline
\end{tabular}

alsolated yields of products; ${ }^{b} \mathrm{BSP}=$ benzenesulfinylpiperidine; ${ }^{\mathrm{c}}$ corresponding glycosylation procedure (see Supporting Information File 1 ); ${ }^{\mathrm{d}}$ starting material was decomposed; ${ }^{e}$ donor was decomposed but acceptor was recovered; ${ }^{f}$ a complex mixture was formed from which the desired disaccharide could not be purified by column chromatography. 
(Table 1, entry 6) was found to be effective in case of donor $\mathbf{6 b}$ and acceptor $\mathbf{5}$ which generated the desired disaccharide $\mathbf{3 a}$ in high yield and exclusive $\alpha$-anomeric selectivity (evidenced from NMR). We presume that this near exclusivity in $\alpha$-selection may be due to the synergistic effect from the 4,6-O-benzylidene group, which is a good promoter for 1,2-cis glycosylation in galactose-based systems [38], as well as the steric crowding caused by the bulky 3-O-naphthylmethyl group at the $\beta$-side of the ring. Having obtained the central disaccharide 3a in requisite yield and excellent stereochemical purity we now proceeded towards the synthesis of the trisaccharide fragment 21 (Scheme 4).

Compound 3a was treated with DDQ in dichloromethane to remove the 3-O-Nap protection group generating acceptor $\mathbf{4}$ in 93\% yield. Glycosylation between donor $\mathbf{2}$ and acceptor $\mathbf{4}$ was achieved uneventfully in the presence of TMSOTf in dichloromethane/ $\mathrm{Et}_{2} \mathrm{O}(4: 1)$ to give the trisaccharide 21 in $70 \%$ yield. Successful glycosylation was also carried out between trisaccharide 21 and ribitol acceptor 7 in the presence of NIS and TMSOTf in dichloromethane at $-20{ }^{\circ} \mathrm{C}$ to give the tetrasaccharide derivative 1 in $89 \%$ yield, thereby finishing the stepwise synthesis of SPn 6A tetrasaccharide 1 in the protected form (Scheme 4).

Having standardized a stepwise synthesis of the tetrasaccharide $\mathbf{1}$ in the protected form we then turned our attention to devise a one-pot protocol to achieve the same derivative. The one-pot synthesis of this target is particularly challenging because of the presence of the two 1,2-cis glycosidic linkages which are likely to make product isolation particularly difficult at the end of the glycosylative protocol. Assuming equal preference of formation for each and every possible diastereomer across the three glycosylation steps a mixture of 8 different diastereomers may be formed if the four monomers are sequentially added in a $(1+1+1+1)$ one-pot strategy. However, the number of possibilities may be reduced to 4 isomers by using a participating group on the rhamnose residue to induce near exclusive $\alpha$-selectivity in the last step. Further reduction can be ensured by incorporating a $(1+2+1)$ approach where the number of possible diastereomers becomes 2 . So, we selected this $(1+2+1)$ glycosylation for our synthesis.

Two different strategies were attempted in this direction. Recently, Mong et al. have reported high $\alpha$-selectivity in the formation of glucan and galactan under non-participating conditions from the O-2 protecting group $[39,40]$. With this method, we tried to couple donor $p$-tolyl 2,3,4,6-tetra- $O$-benzyl-1-thio- $\beta$ D-galactopyranoside (22) with acceptor 4 using a NIS/TMSOTf combination in the presence of DMF acting as a modulating solvent (inset, Scheme 5). Unfortunately, when this strategy was applied to our case it could not produce a viable result. So we switch to the conventional orthogonal strategy for a one-pot synthesis of the targeted tetrasaccharide (Scheme 5).
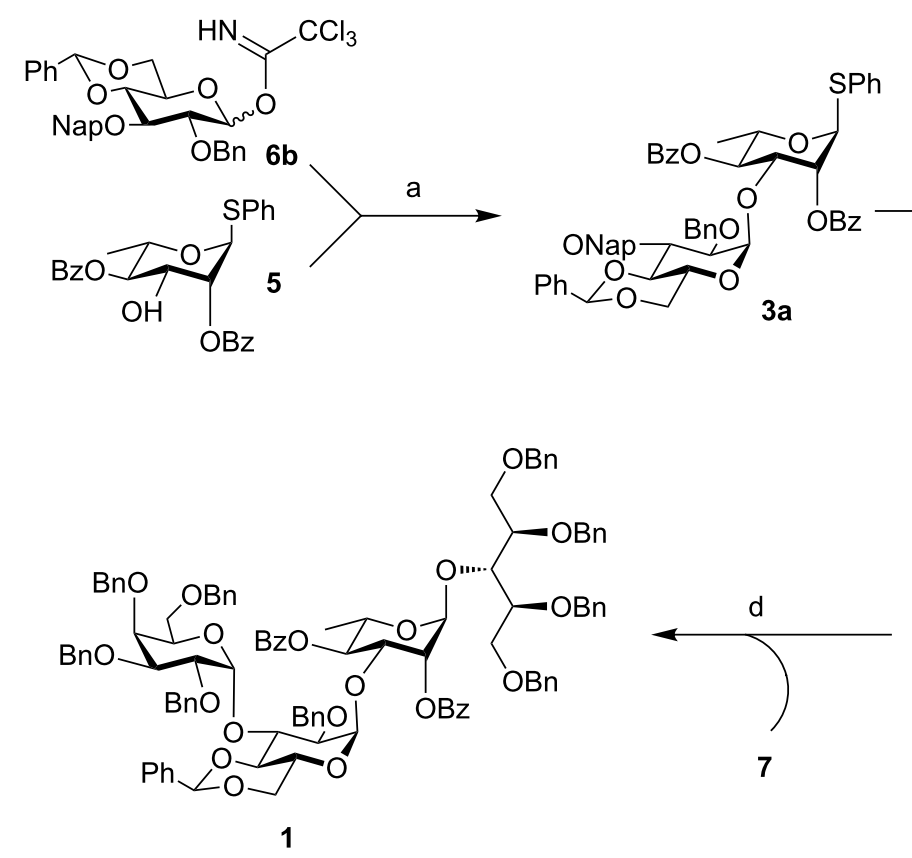

7

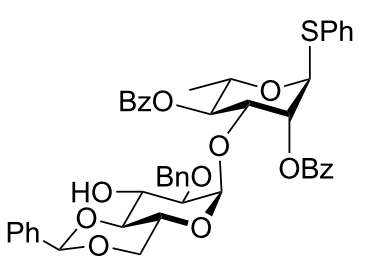

4

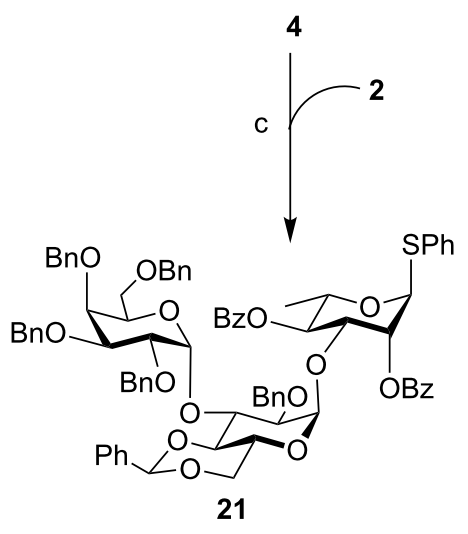

Scheme 4: Stepwise synthesis of tetrasaccharide 1. Reaction conditions: a) TMSOTf, DCM/Et $2 \mathrm{O}(5: 1), 4 \AA \mathrm{MS},-30{ }^{\circ} \mathrm{C}, 75 \%$; b) $\mathrm{DDQ}, \mathrm{DCM} / \mathrm{H}_{2} \mathrm{O}$ (9:1), rt, 93\%; c) TMSOTf, DCM/Et ${ }_{2} \mathrm{O}(4: 1), 4 \AA \mathrm{MS},-15^{\circ} \mathrm{C}, 70 \%$; d) NIS, TMSOTf, DCM, $4 \AA$ MS, $-20^{\circ} \mathrm{C}$, (procedure D, see Supporting Information File 1), $89 \%$. 


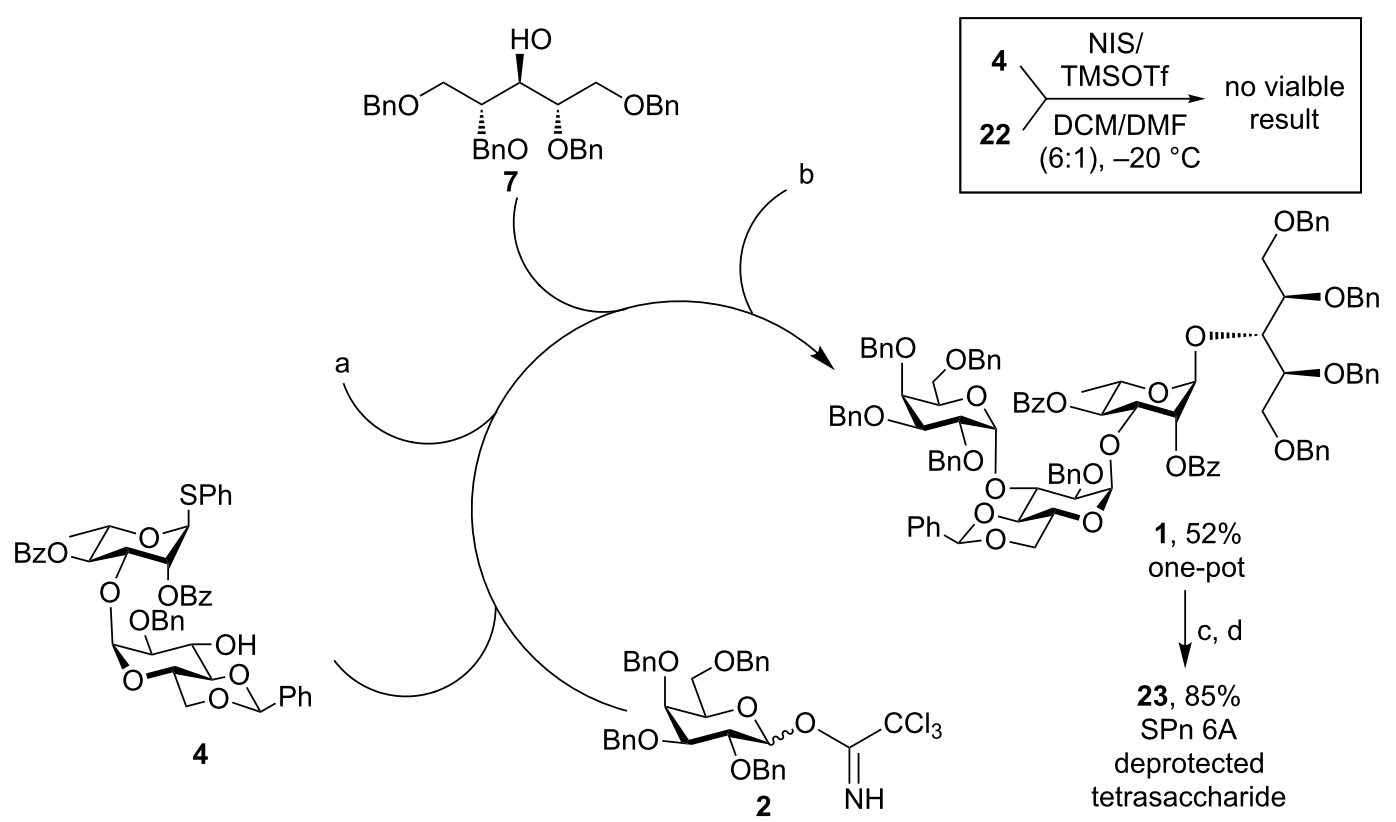

Scheme 5: One-pot synthesis of tetrasaccharide 1. Reaction conditions: a) TMSOTf, $4 \AA$ MS, DCM/Et $\left.{ }_{2} \mathrm{O}(4: 1), \mathrm{N}_{2},-15^{\circ} \mathrm{C}, 1 \mathrm{~h} ; \mathrm{b}\right) \mathrm{NIS}, \mathrm{TMSOTf}$ $-10^{\circ} \mathrm{C}, 45 \mathrm{~min}$; c) $\mathrm{NaOMe}, \mathrm{MeOH}$, rt; d) $\mathrm{H}_{2}, \mathrm{Pd} / \mathrm{C}, \mathrm{EtOH} / \mathrm{EtOAc/AcOH}$, rt.

The disaccharide acceptor 4 was glycosylated with galactosyl trichloroacetimidate donor 2 at $-15{ }^{\circ} \mathrm{C}$ using $30 \mathrm{~mol} \%$ of TMSOTf. After full consumption of the starting materials (TLC), into the same pot the second acceptor 7 followed by NIS were added. The reaction mixture was allowed to reach $-10{ }^{\circ} \mathrm{C}$ before another $30 \mathrm{~mol} \%$ of TMSOTf were added; TLC after 45 minutes showed complete consumption of the starting materials. Thus the targeted tetrasaccharide derivative was prepared via a three component, one-pot sequential glycosylation technique in $52 \%$ yield (Scheme 5). It is to be noted that the temperature had to be raised to $-10{ }^{\circ} \mathrm{C}$ from $-20{ }^{\circ} \mathrm{C}$ in the second step of the one-pot protocol. This was necessary to improve the overall yield of the final product. The tetrasaccharide derivative 1 was next deprotected under Zemplén conditions [41], followed by hydrogenation with $\mathrm{H}_{2} / \mathrm{Pd}-\mathrm{C}$ in $\mathrm{EtOH} / \mathrm{EtOAc} / \mathrm{AcOH}$ solvent to give the deprotected tetrasaccharide 23 in $85 \%$ yield over two steps.

${ }^{1} \mathrm{H}$ NMR in $\mathrm{D}_{2} \mathrm{O}$ of the target tetrasaccharide 23 showed the anomeric protons of the galactose, glucose, and rhamnose residues from the non-reducing end appearing at $\delta 5.32$ $(\mathrm{d}, J=3.5 \mathrm{~Hz}), \delta 5.02(\mathrm{~d}, J=3 \mathrm{~Hz})$, and $\delta 4.93(\mathrm{bs})$, respectively. ${ }^{13} \mathrm{C}$ NMR along with the HSQC in the same solvent revealed that the chemical shifts of the anomeric carbons of the same units from the non-reducing end are at $\delta 99.2$ $\left({ }^{1} J_{\mathrm{C} 1-\mathrm{H} 1}=167.7 \mathrm{~Hz}\right), 95.4\left({ }^{1} J_{\mathrm{C} 1-\mathrm{H} 1}=169.3 \mathrm{~Hz}\right)$ and 100.1 $\left({ }^{1} J_{\mathrm{C} 1-\mathrm{H} 1}=169.2 \mathrm{~Hz}\right)$, respectively. The values are indicative of $\alpha$-stereochemistry at all the anomeric centers [42]. Moreover, the chemical shifts were found to be in fair agreement with the reported C-1 chemical shifts at $\delta 99.5,95.6$, and 100.3, exhibited in $\mathrm{D}_{2} \mathrm{O}$ corresponding to the anomeric centers of compound 23 [22].

\section{Conclusion}

Summarizing our work we have achieved stepwise and sequential one-pot syntheses of the tetrasaccharide repeating unit of SPn 6A via an orthogonal glycosylation strategy using commonly used trichloroacetimidate and thioglycoside donors. The challenging 1,2-cis linkages could be prepared with a yield and a selectivity which were high enough to allow the one-pot synthesis.

\section{Supporting Information}

\section{Supporting Information File 1}

Experimental details for the preparation of compounds 1, 3a, 4, 5, 6a, 6b, 7, 12a, 19, 20, 21, and 23 and the corresponding characterization data. [https://www.beilstein-journals.org/bjoc/content/ supplementary/1860-5397-14-95-S1.pdf]

\section{Supporting Information File 2}

${ }^{1} \mathrm{H}$ and ${ }^{13} \mathrm{C}$ NMR of compounds 1, 3a, 4, 5, 6a, 6b, 7, 12a, 19, 20, 21, and 23 and 2D NMR (COSY, HSQC and HMBC) of compound 23.

[https://www.beilstein-journals.org/bjoc/content/ supplementary/1860-5397-14-95-S2.pdf] 


\section{Acknowledgements}

RG acknowledges the SERB, DST (Scheme No. SR/S1/OC-61/ 2012), India for financial support. AC and MMM are thankful to the CSIR and UGC, India, respectively, for providing senior research fellowships.

\section{ORCID ${ }^{\circledR}$ iDs}

Rina Ghosh - https://orcid.org/0000-0002-6506-5089

\section{References}

1. Kuberan, B.; Linhardt, R. J. Curr. Org. Chem. 2000, 4, 653. doi:10.2174/1385272003376111

2. Danishefsky, S. J.; Allen, J. R. Angew. Chem., Int. Ed. 2000, 39, 836. doi:10.1002/(SICI)1521-3773(20000303)39:5<836::AID-ANIE836>3.0. CO;2-I

3. Wong, C.-H., Ed. Carbohydrate-Based Drug Discovery; Wiley-VCH: Weinheim, Germany, 2003. doi:10.1002/3527602437

4. http://www.who.int/mediacentre/factsheets/fs331/en/ (accessed Sept 15, 2016).

5. Kamerling, J. P. In Streptococcus pneumonia, Molecular Biology and Mechanism of Disease; Tomasz, A., Ed.; Mary Ann Liebert: Larchmont, New York, NY, 2000.

6. Park, I. H.; Pritchard, D. G.; Cartee, R.; Brandao, A.; Brandileone, M. C. C.; Nahm, M. H. J. Clin. Microbiol. 2007, 45, 1225. doi:10.1128/JCM.02199-06

7. Robinson, D. A.; Briles, D. E.; Crain, M. J.; Hollingshead, S. K. J. Bacteriol. 2002, 184, 6367. doi:10.1128/JB.184.22.6367-6375.2002

8. Rebers, P. A.; Heidelberger, M. J. Am. Chem. Soc. 1961, 83, 3056. doi:10.1021/ja01475a021

9. Robbins, J. B.; Lee, C. J.; Rastogi, S. C.; Schiffman, G.; Henrichsen, J. Infect. Immun. 1979, 26, 1116.

10. Robbins, J. B.; Austrian, R.; Lee, C.-J.; Rastogi, S. C.; Schiffman, G.; Henrichsen, J.; Makela, P. H.; Broome, C. V.; Facklam, R. R.; Tiesjema, R. H.; Parke, J. C., Jr. J. Infect. Dis. 1983, 148, 1136. doi:10.1093/infdis/148.6.1136

11. Alonsodevelasco, E.; Verheul, A. F. M.; Verhoef, J.; Snippe, H. Microbiol. Rev. 1995, 59, 591.

12. Moreau, M.; Schulz, D. J. J. Carbohydr. Chem. 2000, 19, 419. doi:10.1080/07328300008544091

13. Ledwith, M. Curr. Opin. Pediatr. 2001, 13, 70. doi:10.1097/00008480-200102000-00013

14. Väkeväinen, M.; Eklund, C.; Eskola, J.; Käyhty, H. J. Infect. Dis. 2001, 184, 789. doi:10.1086/322984

15. Eschaniz-Aviles, I. G.; Solorzano-Santos, F. Salud Publica Mexico 2001, 43, 352.

16. Zon, G.; Szu, S. C.; Egan, W.; Robbins, J. D.; Robbins, J. B. Infect. Immun. 1982, 37, 89.

17. Slaghek, T. M.; van Vliet, M. J.; Maas, A. A. M.; Kamerling, J. P.; Vliegenthart, J. F. G. Carbohydr. Res. 1989, 195, 75. doi:10.1016/0008-6215(89)85090-6

18. Slaghek, T. M.; van Oijen, A. H.; Maas, A. A. M.; Kamerling, J. P.; Vliegenthart, J. F. G. Carbohydr. Res. 1990, 207, 237. doi:10.1016/0008-6215(90)84051-U

19. Thijssen, M. J. L.; van Rijswijk, M. N.; Kamerling, J. P.; Vliegenthart, J. F. G. Carbohydr. Res. 1998, 306, 93. doi:10.1016/S0008-6215(97)00271-1
20. Thijssen, M. J. L.; Bijkerk, M. H. G.; Kamerling, J. P.; Vliegenthart, J. F. G. Carbohydr. Res. 1998, 306, 111. doi:10.1016/S0008-6215(97)10013-1

21. Slaghek, T. M.; Maas, A. A. M.; Kamerling, J. P.; Vliegenthart, J. F. G. Carbohydr. Res. 1991, 211, 25. doi:10.1016/0008-6215(91)84143-3

22. Parameswar, A. R.; Pornsuriyasak, P.; Lubanowski, N. A.; Demchenko, A. V. Tetrahedron 2007, 63, 10083. doi:10.1016/j.tet.2007.07.036

23. Demchenko, A. V.; Rousson, E.; Boons, G.-J. Tetrahedron Lett. 1999, 40, 6523. doi:10.1016/S0040-4039(99)01203-4

24. Parameswar, A.; Hasty, S. J.; Demchenko, A. V. Carbohydr. Res. 2008, 343, 1707. doi:10.1016/j.carres.2008.03.035

25. Parameswar, A. R.; Park, I. H.; Saksena, R.; Kováč, P.; Nahm, M. H.; Demchenko, A. V. ChemBioChem 2009, 10, 2893. doi:10.1002/cbic.200900587

26. Schmidt, R. R.; Michel, J.; Roos, M. Liebigs Ann. Chem. 1984, 1343. doi:10.1002/jlac.198419840710

27. Rao, Y.; Boons, G.-J. Angew. Chem., Int. Ed. 2007, 46, 6148. doi:10.1002/anie.200701750

28. Weingart, R.; Schmidt, R. R. Tetrahedron Lett. 2000, 41, 8753. doi:10.1016/S0040-4039(00)01497-0

29. Mukherjee, M. M.; Basu, N.; Chaudhury, A.; Ghosh, R. RSC Adv. 2016, 6, 109301. doi:10.1039/C6RA23198E

30. Basu, N.; Maity, S. K.; Roy, S.; Singha, S.; Ghosh, R. Carbohydr. Res. 2011, 346, 534. doi:10.1016/j.carres.2011.01.003

31. Garegg, P. J.; Kvarnström, I.; Niklasson, A.; Niklasson, G.; Svensson, S. C. T. J. Carbohydr. Chem. 1993, 12, 933. doi:10.1080/07328309308020107

32. Müller, M.; Schmidt, R. R. Eur. J. Org. Chem. 2001, 2055. doi:10.1002/1099-0690(200106)2001:11<2055::AID-EJOC2055>3.0.C $0 ; 2-\mathrm{N}$

33. Basu, N.; Maity, S. K.; Chaudhury, A.; Ghosh, R. Carbohydr. Res. 2013, 369, 10. doi:10.1016/j.carres.2013.01.001

34. Sumida, Y.; Kokubo, S.; Kunisada, S.; Miyamoto, S. Immunostimulants containing polysaccharides comprising $\beta-1,3$-glucan as main chain and $\beta$-1,3-glucan side chains attached via $\beta 1 \rightarrow 6$ bond, and antitumor agents containing them. Jpn. Kokai Tokkyo Koho JP2005225775 A, Aug 25, 2005.

35. Meier, L.; Monteiro, G. C.; Baldissera, R. A. M.; Sá, M. M. J. Braz. Chem. Soc. 2010, 21, 859. doi:10.1590/S0103-50532010000500013

36. Crich, D.; Vinogradova, O. J. Org. Chem. 2007, 72, 3581. doi:10.1021/jo062411p

37. Xie, Z.-F.; Suemune, H.; Sakai, K. Tetrahedron: Asymmetry 1993, 4, 973. doi:10.1016/S0957-4166(00)80142-1

38. Crich, D. Acc. Chem. Res. 2010, 43, 1144. doi:10.1021/ar100035r

39. Lu, S.-R.; Lai, Y.-H.; Chen, J.-H.; Liu, C.-Y.; Mong, K.-K. T. Angew. Chem., Int. Ed. 2011, 50, 7315. doi:10.1002/anie.201100076

40. Liu, C.-Y. I.; Mulani, S.; Mong, K.-K. T. Adv. Synth. Catal. 2012, 354, 3299. doi:10.1002/adsc.201200396

41. Zemplén, G. Ber. Dtsch. Chem. Ges. 1926, 59, 1254. doi:10.1002/cber.19260590626

42. Bock, K.; Pedersen, C. J. Chem. Soc., Perkin Trans. 2 1974, 293. doi:10.1039/p29740000293 


\section{License and Terms}

This is an Open Access article under the terms of the Creative Commons Attribution License

(http://creativecommons.org/licenses/by/4.0), which permits unrestricted use, distribution, and reproduction in any medium, provided the original work is properly cited.

The license is subject to the Beilstein Journal of Organic Chemistry terms and conditions:

(https://www.beilstein-journals.org/bjoc)

The definitive version of this article is the electronic one which can be found at:

doi:10.3762/bjoc. 14.95 